\title{
VESTED AND CONTINGENT INTERESTS AND THE RULE AGAINST PERPETUITIES.
}

Mir. Kales ${ }^{1}$ takes the ground that Mr. Gray's exposition of the distinction between vested and contingent interests is capable of some further development. Mr. Kales then makes some criticism on the definition given by Mr. Gray, and on his position as to the application of the rule against perpetuities to remainders. He points out that it is of vital importance to a writer on the rule against perpetuities to know what the exact difference is betwcen a vested and contingent remainder. It is proposed in this article to offer a few suggestions on the subject.

What is a contingent remainder, and what is the exact nature, if it can be ascertained, of the contingency upon which a contingent remainder is contingent?

According to the principle of the common law, there could be no interval between the preceding estate and the remainder. The remainder must fall into place immediately upon the termination of the preceding estate, and if it did not do so, its opportunity to take effect as a remainder was gone forever.

An estate, therefore, which was so linited that it might not take effect as a remainder at the proper time, was said to be a contingent remainder, by which, it is.apprehended, was meant that it was contingent whether it would ever be a remainder.

The contingency then, upon which a contingent remainder is contingent, is the uncertainty that it will take effect

'Article, "Several Problems of Gray's Rule Against Perpetuities, Second Edition," 20 Harvard Law Review, 192, 1907. See article by Mir. Kales, "Future Interests in Land," 22 Law Quar. Review, 250, 383, July-October, 1906, and criticism thereon, in 20 Harvard Law Review, 243, 1907. 
immediately upon the termination of the preceding particular estate, which will happen whenever it is limited to take effect upon an event other than the termination of the preceding particular estate itself. If the event happens too late, the remainder camnut make connection with the preceding particular estate, and therefore is not a remainder at all. It is nothing.

This might occur in two ways: (I) because the event upon which the remainder was limited to take effect might not happen before the termination of the preceding particular estate; (2) where the remainder was limited to a person not yet ascertained, or who might not be ascertained before the termination of the preceding particular estate. ${ }^{2}$

All four classes of Mr. Fearne may be reduced to these two heads.

Mr. Fearne's four classes, as quoted by Mr. Josiah Smith in his treatise on Executory Interests, at page 65 , are as follows:

I. "Where the remainder depends entirely on a contingent determination of the preceding estate itself; as if A makes a feoffment to the use of $B$ till $C$ returns from Rome, and after such return of $C$, then to remain over in fee."

II. "Where the contingency on which the remainder is to take effect, is independent of the determination of the preceding estate; as if a lease be made to $\mathrm{A}$ for life, remainder to $B$ for life, and if $B$ dies before $A$, remainder to $\mathrm{C}$ for life."

III. "Where a remainder is limited to take effect on an event, which. though sure to happen some time or other, yet may not happen until after the determination of the particular estate; as if a lease be made to J. S. for life, and after the death of J. D., the lands to remain over to another in fee."

\footnotetext{
${ }^{2}$ This is the classification suggested by Lord Chief Justice Willes, in Smith v. Packlhurst, 3 Atk., 135, 1742, (I) where a remainder is limited to a person not in being, and who may possibly never exist; (2) where the remainder depends on a contingency collateral to the continuance of the particular estate.
} 
IV. "Where a remainder is limited to a person not ascertained, or not in being. at the time when such limitation is made;" as if a lease be made to one for life, remainder to the right heirs of J. S., who is living; or remainder to the first son of $B$, who has no son then born; or if an estate be limited to two for life, remainder to the survivor of them in fee."

As to Mr. Fearne's classification, it may be observed, as to the first class, that the remainder may never take effect at all, if the contingency upon which the particular estate is to determine never happens, or happens after the preceding particular estate has regularly come to an end. The termination of the preceding estate, therefore, is a termination by the happening of a collateral event which is uncertain. That the second and third classes are practically the same. The second is where the contingency is independent of the termination of the preceding particular estate; and the third, where the event may happen after the termination of the preceding particular estate. The third, therefore, is simply a sub-division of the second, and in all these cases, if the event happens after the termination of the preceding estate, the remainder is roid, not because it is limited upon a contingency, but because there is then a gap between the termination of the preceding estate and the beginning of the next estate, which gap or -beyance in seisin was not permitted by the common law.

The first three classes of Mr. Fearne may therefore be reduced to the second class of Lord Chief Justice Willes, which may be stated thus: Cases where the remainder is limited to take effect upon the happening of an event other than the regular termination of the preceding particular estate.

There remains, therefore, the fourth class of Mr. Fearne and the first class of Lord Chief Justice Willes, where

"Mr. Smith's statement is valuable, as he adds an example. of each class. 
the person who is to take is unascertained, which is obviously not reducible to the same principle as obtains in the other class. As to this class, a distinction must be taken: In the case of a devise to $A$ for life, and after his death to the heirs of $\mathrm{B}$, a living person, the remainder to the heirs of $B$ is contingent. It partakes, however, of the first class, in that there is a contingency upon which the remainder may never take effect, that is, if $B$ survives $A$, and may be considered as belonging to the second class, in that the persons who are to take (the heirs of $B$ ) are unascertained. Where there is a devise to $A$ for life, and after his death to his heirs, the case is different. Here there is no contingency that the limitation will never take effect as a remainder. It will fall in place immediately upon the death of $\mathrm{A}$. The remainder is said to be contingent because there is no one ascertained at the present time to take, which leads to a consideration of the other difficulty which was felt at common law in allowing the validity of contingent remainders.

Under the feudal theory, the fee was the unit of ownership in land, and no subdivision of that unit could be allowed which would interfere with the feudal duties due to the lord of the fee. If, therefore, the owner of the fee made a grant thereof, and divided it into smaller particular estates, he must so limit such estates that they fit together exactly, one after the other, without interval or overlap. There could not be two persons occupying the fee at the same time, and there could be no interval of time when the fee was unoccupied.

It was therefore apparent, that a contingent remainder being only a possibility until the event happened, existed solely outside of the fee, and had no place in the compact mass of estates into which the fee was divided until the event happened. When that occurred, the remainder, which was to be valid, must take its place with the other estates, and in some manner acquire a portion of the seisin of the fee. Some estate must be displaced in order to make room 
for the new member, and as there was no feoffment upon the happening of the contingency, the common law lawyers found great difficulty in evolving any theory upon which the seisin could pass to the newly arrived remainderman. The difficulty was finally overcume, however, by the fiction of saying that the seisin renained in the feoffer until the happening of the event, and then passed on from him to the remainderman.

A contingent remainder, therefore, may be defined as follows: A contingent remainder was, at common law, a limitation of an interest in real estate, which might never take effect as a remainder owing to the circumstance that it was limited to an unascertained person, or limited to take effect upon an event other than the regular termination of the preceding particular estate. ${ }^{4}$

A vested remainder at common law was an estate given to an ascertained individual and limited to take effect upon no other event than the regular termination of the preceding particular estates

Mr. Kale, in the article above referred to, ${ }^{\circ}$ points out that the conception of what is a contingent remainder has changed in modern times. He instances: The cases which present themselves under modern statutes, of how far a contingent remainderman has a right to ask for partition or call trustees to account. In such cases, the courts have

- Mr. Gray offers no definition of a contingent remainder. Mrr. Fearne's definition is as follows, Contingent Remainders, page 3 : " $A$ contingent remainder is a remainder limited so as to depend on an event or condition which nay never happen or be performed, or which may not happen or be performed till after the determination of the preceding estate, for if the preceding estate determine before such event or condition happens, the remainder will never take effect."

- Mr. Gray (Rule against Perpetuities, 2nd edit., see Ior) draws the line between vted and contingent remainders thus: "A remainder is vested in $A$, when throughout its continuance $A$, or $A$ and his heirs, have the right to inmediate possession whenever and however the preceding estate may determine." Does not a remainder coming within the definition suggested fulfill the requirement laid down by the learned author?

- 20 Harvard Law Review, 192, 1907. 
abandoned the feudal notion of what is a remainder, and it is submitted, rightly so. At common law, a remainder was none the less rested even though it might never take effect. It would be absurd, however, to permit a person who might never have any interest in the land, to compel a partition, or permit a person who might never have any interest in the fund, to compel the trustee to file an account. It would seem, therefore, to be a practical common sense rule, that the only person who could compel proceedings in such cases would be a person who possessed an interest which was sure to come into effect. This difference, therefore, in the conception of what is a contingent remainder is explainable by the practical necessities of the case.

\section{THE RULE AGAINST PERPETUITIES.}

The rule against perpetuities, as finally defined by Mr. Gray," is as follows: "No interest is good uniess it must vest, if at all, not later than twenty-one years after some life in being at the creation of the interest."

It is submitted, with difficlence, however, that this is not the rule against Perpetuities at all. The rule itself destroys certain interests limited upon contingencies which may occur after a certain period.

The interests which the rule does not destroy, that is, which are not within its purview, are the interests which are good. So far as the rule is concerned, Mr. Gray's statcment, therefore, simply describes the class of future interests to which the rule does not apply. It is therefore respectfully submitted that it is not a statement of the rule at all. The relation which Mr. Gray's statement bears to the rule itself may be shown by an illustration: Suppose an act were passed, making it unlawful to enter a dwelling house after eleven o'clock at night without the consent of the owner. If there were no further law on the subject, an entry in the daytime without the consent of the owner

'Gray on Perpetuitiès, and edit., sec. 201. 
would be lawful. The law punishes an entry made after eleven o'clock. It is, however, a statement only of the practical result of the law to say, that no entry in a dwelling house, without the consent of the owner, is lawful unless made before eleven o'clock at night.

If we assume that the rule does not apply to vested interests, it must be stated so as to destroy only contingent interests, and the following form is suggested:

All future interests which are limited to an unascertained person, or to take effect upon a contingency other than the regular termination of the preceding particular estate, are void whenever such person may possibly not be ascertained before, or the contingency may happen after, the expiration of a life or lives in being at the creation of the interest, and twenty-one years thereafter. It is believed, that this statement of the rule is clearer and more easily understood than the one suggested by Mr. Gray, and when borne in mind in this form, many difficulties in the subject will disappear. ${ }^{8}$

\section{ROLAND R. FOULKE.}

This is very much the language in which the learned author himself referred to the Rule (Gray, Restraints on Alienation, and edit. sec. $2 ; 2$ ), where he said: "The Rule against Perpetuities declares that every estate or interest which requires the happening of a contingency or the arrival of a time certain as a condition precedent, is bad unless the contingency must happen or the time must arrive within a life or lives in being and twenty-one years." 